\title{
Wpływ Internetu na relacje w grupie osób homoseksualnych w Toruniu
}

\section{Wprowadzenie}

nternet zrewolucjonizował współczesny świat. Wpłynął znacząco na wiele sfer naszego życia, od pozyskiwania informacji, przez robienie zakupów, po szukanie uczucia. Cyberprzestrzeń umożliwia nam dowolne kształtowanie swojej wirtualnej tożsamości, pozwala poczuć się jak ktoś, kim zawsze chcieliśmy się stać. Przestaje być ona postrzegana tylko jako postęp, skok technologiczny. Kusi nas bezpieczeństwem, które obiecuje anonimowość Internetu. Świat wirtualny w dzisiejszych czasach tak silnie determinuje rzeczywistość, że możemy spotkać się nie z koncepcjami człowieka myślącego (homo sapiens), a z koncepcjami "„złowieka elektronicznego" (homo cyber). "Człowiek elektroniczny" "jest istotą zanurzoną w cybernetycznej matrycy komputerowej, marzącej o bezcielesnym byciu, świadomości uwolnionej z więzienia ciała i przeniesionej w cyfrową rzeczywistość stworzoną przez komputer". Manuel Castells oskarżał Internet o bycie „ucieczką od prawdziwego świata” [Loska 2001: 145]. Zapewne miał w tym dużo racji. Jednak to stwierdzenie nie może być traktowane jako uniwersalne. Istnieją grupy społeczne, które nie znajdują miejsca w przestrzeni publicznej kreowanej przez media tradycyjne. I o ile nie istnieją one w prasie, telewizji czy radiu, o tyle są obecne w Internecie. Osoby homoseksualne płci męskiej są dobrym tego przykładem. Według Marty Klimowicz [2006: 310], autorki artykułu Connecting to reality - polscy geje W Internecie: „geje, łącząc się z Internetem, łączą się ze swoją rzeczywistością". Zdanie to stanowi istotę niniejszego artykułu. 
Celem, jaki przyświecał tworzeniu tejże pracy, było zbadanie wpływu Internetu na grupę toruńskich gejów. Homoseksualiści stanowią wspólnotę hermetyczną, dlatego też studia o takiej tematyce należą do rzadkości. Był to jeden z powodów, dla których zdecydowano się podjąć nieheteronormatywny wątek. Drugim była świadomość, że dla tej akurat grupy społecznej Internet ma ogromną wagę. Problem rozpatrywano na trzech płaszczyznach: (1) wpływu Internetu na grupę, (2) na jednostkę oraz (3) na komunikację. Praca ta opiera się na badaniach własnych. Przeprowadzono je za pomocą dwóch metod: (1) analizy treści portali internetowych oraz (2) wywiadu pogłębionego z jedenastoma homoseksualistami z Torunia. W badaniu wzięły udział osoby homoseksualne płci męskiej i takich też osób dotyczy ta praca. W trakcie jej powstawania wykorzystano badania przeprowadzone przez Martę Klimowicz, zawarte w wyżej wspomnianym artykule.

\section{Wpływ na grupę}

\subsection{Etapy kształtowania się grupy}

Etap pierwszy to lata przed 1989 rokiem. Wówczas dominowały anonimowe kontakty seksualne na pikiecie. Pikieta to odosobnione miejsce, w którym osoby homoseksualne mogą spotykać się anonimowo w celu odbycia stosunku seksualnego. W Toruniu znajduje się ona na wzniesieniu naprzeciw dworca PKS. Informacje na jej temat rozchodziły się tylko w gronie osób homoseksualnych. Dla dwóch z naszych rozmówców była to początkowo jedyna forma kontaktu z innymi osobami homoseksualnymi, dla trzeciego - forma urozmaicenia życia erotycznego. Pikieta miała charakter czysto hedonistyczny, seksualny. Osoby przychodzące na nią zazwyczaj się nie znały. Kontakty ograniczały się do zaspokajania potrzeb seksualnych oraz do szczątkowego informowania o podobnych miejscach. Homoseksualiści czerpali wiedzę na temat swojej orientacji głównie z funkcjonujących w społeczeństwie stereotypów. Ich dochodzenie do własnej tożsamości seksualnej odbywało się ze znacznym opóźnieniem. Etap ten charakteryzował się dezintegracją normatywną [Lewandowski i in. 2011: 69].

Etap drugi obejmuje lata od przełomu w 1989 roku do pojawienia się nowych mediów. Po zmianie ustroju zaczęły pojawiać się pierwsze kluby dla osób homoseksualnych. Dochodziło wówczas do pionierskich 
przeobrażeń na skalę krajową. W Toruniu zaczęła formować się grupa stałych bywalców gejbarów. To niosło za sobą wiele konsekwencji, m.in. zanik anonimowości, zwiększenie liczby członków toruńskiej grupy, wzrost świadomości grupowej, początek integracji. Specyficzna stała się sieć symboli i metafor językowych służąca w komunikacji bilateralnej. To moment zaniku anonimowości, w którym dominują kontakty bezpośrednie w klubie gejowskim. Anonimowość tę mają podtrzymywać pseudonimy. W tym okresie powstają pierwsze organizacje homoseksualne. Ponadto przemiany w 1989 roku spowodowały pojawienie się pierwszych gazet, czasopism, ulotek i informatorów dla osób homoseksualnych. Dochodzenie do własnej tożsamości seksualnej odbywało się przez kontakt seksualny z innymi homoseksualistami, wymianę doświadczeń oraz przez funkcjonujące w społeczeństwie stereotypy. Etap ten cechowała integracja grupowa [Lewandowski i in. 2011: 71].

Werner S. Landecker [za: Kochanowski 2004: 157-159] podzielił integrację na cztery typy: integrację kulturalną, integrację normatywną, integrację komunikacyjną, integrację funkcjonalną. Odnosząc się do tego podziału, możemy zauważyć, że integrację kulturalną gejów widać przez te same stroje, słownictwo, metafory, zachowania, seksualny styl życia. Integracji normatywnej można doszukać się w podobnym podejściu do norm i wartości moralnych (częstotliwość zmiany partnerów, zdrada, przygodny seks), ale również do penalizowania pewnych zachowań przez członków grupy, np. wykluczenie lub stygmatyzacja. Integracja komunikacyjna przejawia się w zmianie kontaktów $z$ anonimowych na imienne, zwiększeniu częstotliwości spotkań (zmniejszenie przypadkowości, regularne odwiedziny). Skutkuje to również odizolowaniem się od reszty społeczeństwa, gdyż są ku temu warunki. Integracja funkcjonalna to przede wszystkim stopień zależności danych członków od siebie.

O ile w fazie pikiet podstawowe znaczenie miały zależności seksualne, o tyle aktualnie możemy mówić również o emocjach i uczuciach, takich jak przyjaźń czy miłość. Ponadto pojawiają się zależności towarzyskie, czyli samo obcowanie w grupie. Powstające kluby stanowiły ważny etap w formowaniu się grupy. Pokazały, że zjawisko homoseksualności jest dość powszechne. Wówczas tworzono także pierwsze organizacje dla osób nieheteronormatywnych, które są naturalnym wynikiem powstania grupy. Organizacje te przede wszystkim aktywnie działały, i nadal działają, na rzecz tolerancji seksualnej (Kampania Przeciw Homofobii, Stowarzyszenie Pracownia Różnorodności). Ponadto należy zauważyć, że powstał nie- 
znany wcześniej rodzaj instytucji nieformalnej - związek partnerski. Rola przedstawionych wyżej instytucji była bardzo istotna. Umożliwiały one osiąganie celów grupowych, uczyły ról społecznych, gwarantowały spójność i identyfikację z grupą, aż wreszcie zapewniały jej ciągłość [Lewandowski i in. 2011: 73].

Etap trzeci to rewolucja medialna. Nie można dokładnie określić jej początku, gdyż był on związany z indywidualnym dostępem do Internetu toruńskich homoseksualistów. Rewolucja medialna rozpoczęła się od uświadomienia sobie szeregu możliwości, które stwarzają nowo powstałe środki - nowe media (czaty, komunikatory, portale, e-gazety). To etap ponownego zaniku anonimowości, kształtowania się szerokiej świadomości grupowej oraz aktywnej działalności toruńskich homoorganizacji w świecie wirtualnym. Warto podkreślić, że Internet ułatwiał dostęp do tego typu instytucji wszystkim członkom grupy naraz. Ponadto następowało również przyspieszenie $w$ samookreśleniu własnej tożsamości. Informacje czerpano z kontaktów, a także wymiany doświadczeń za pośrednictwem sieci. Wyjaśnień oraz wszelakich naukowych doniesień związanych z kwestiami homoseksualnymi można było odtąd poszukiwać bez skrępowania w świecie wirtualnym. Dodatkowo komunikacja pośrednia została umasowiona. Dla tego etapu typowa była dezintegracja grupowa.

Otóż pozorna dezintegracja grupy stanowi skutek pojawienia się Internetu. Zazwyczaj dezintegracja wiąże się z brakiem informacji lub kanałów jej przepływu. W tym wypadku nastąpiło jednak przewartościowanie komunikacji. Mianowicie nowe medium, jakim jest Internet, sprawiło, że możliwa stała się komunikacja z grupą bez uczestnictwa w niej w sposób bezpośredni. Dobrym tego przykładem są osoby identyfikujące się z homoseksualistami, ale nieuczestniczące w życiu grupy. Dotyczy to przede wszystkim ludzi młodych, którzy uzyskali dostęp do Internetu w okresie swojego dojrzewania płciowego i emocjonalnego. Pozostali również doceniają rolę Internetu na tym polu [Lewandowski i in. 2011: 56].

Innym czynnikiem wpływającym na dezintegrację jest heterogeniczność i złożoność grupy. Pojawienie się nowych mediów spowodowało rozrost grupy, a to wpłynęło na heterogeniczność jej homoseksualnych członków. To zaś powoduje dezintegrację przez rozwarstwienie oraz tendencje izolacyjne niektórych członków i grup członków. Niemniej mamy do czynienia z brakiem wyboru przynależności osób homoseksualnych do innych społeczności. Powoduje to swoisty paradoks, czego egzemplifikacją jest efekt małej grupy, czyli dominacja potrzeby przynależności i iden- 
tyfikacji z grupą nad niektórymi cechami jednostki [Wallace 2001: 125]. Kolejnym czynnikiem dezintegracyjnym jest konflikt ról. W tym wymiarze wiąże się on ściśle z poszukiwaniem partnerów.

\subsection{Internet a grupa}

Pojawienie się nowych mediów zasadniczo wpłynęło na zmianę grupy toruńskich gejów - nastąpił znaczny jej rozrost. Dotychczas homoseksualiści komunikowali się w sposób bezpośredni, stąd grupa ta była stosunkowo nieliczna. Według seksuologa Zbigniewa Lwa-Starowicza [1999: 18] zbiorowość osób homoseksualnych w Polsce wynosi od 4 do $6 \%$ ogółu społeczeństwa. Zatem w Toruniu daje to wynik od 8200 do 12300 osób. Liczbę toruńskich homoseksualistów internautów można oszacować na 1000 osób (935 osób wpisało Toruń w rubryce "miasto" w trakcie rejestracji na najpopularniejszym portalu dla gejów - fellow.pl). W związku z tym mamy do czynienia ze znacznym zagęszczeniem stosunków, a co za tym idzie ze spadkiem integralności jej członków.

Opisując zbiorowość gejów w Toruniu, powinniśmy zastanowić się, czy możemy określić ją mianem grupy społecznej oraz czy występuje w niej zjawisko świadomości grupowej. Wspólne wartości stanowią cechę charakteryzującą grupę społeczną. W przypadku grupy osób homoseksualnych mają one przede wszystkim naturę seksualną oraz psychospołeczną (potrzeba akceptacji, potrzeba przynależności grupowej). Ponadto możemy wyszczególnić wartości o podłożu towarzyskim i rozrywkowym, jak i te związane z działaniami podtrzymującymi istnienie innych orientacji seksualnych w świadomości społeczeństwa. Innym aspektem grupy społecznej jest wytwarzanie przez nią wspólnych norm i kar. Zaczęły obowiązywać takie sankcje, jak wykluczenie ze znajomych czy umieszczenie komentarza. Wszelkiego rodzaju wykroczenia spotykają się w grupie z reprymendą (w postaci krytyki lub pouczenia) ze strony członków [Lewandowski i in. 2011: 48]. Niekiedy dochodzi do odzewu ze strony osób, które łamią ustalone normy, używając np. przesadnego, wulgarnego języka, przesyconego erotyzmem. Najczęściej jednak dochodzi do przeprosin, rzadziej do kwestionowania zarzutów. Schemat ten jest podobny do opisanego przez Magdalenę Szpunar [2004: 116] postępowania w przypadku dopuszczenia się wykroczenia w wirtualnej grupie heteroseksualnej. W ten sposób geje w Internecie doświadczają swoistej socjalizacji wtór- 
nej - odkrywają, co wypada, a co jest źle widziane w środowisku nieheteroseksualnym. Internet, stwarzając nową rzeczywistość, wykreował nowe wzorce homoseksualne.

Odwołując się do teorii jaźni odzwierciedlonej Ervina Goffmana i Charlesa Cooleya [za: Bierówka 2009: 119], możemy wyszczególnić sposoby zachowania homoseksualistów w grupie. Według tej teorii ludzie zachowują się tak, jak wymaga tego od nich środowisko. Przekładając to na badanych, można zauważyć absorbowanie przez nich języka, słownictwa oraz przyjęcie roli homoseksualisty - promiskuity, który nie wzbudza negacji w środowisku homoseksualnym. Niektóre osoby były ubrane podczas wywiadu w bluzy w ostrych kolorach (jaskrawobłękitny, czerwony), obcisłe spodnie, białe adidasy. Następnie osoby, które były pytane o charakterystyczny strój, omawiały go, patrząc na siebie i nie ukrywając w ten sposób przejęcia od grupy jej charakterystycznych cech.

Kolejnym aspektem wartym rozpatrzenia jest świadomość grupowa. Świadomość ta to świadomość uczestnictwa, pełnienia roli społecznej oraz partycypacja [Bierówka 2009: 74]. Osoby homoseksualne z całą pewnością czują przynależność do grupy i uczestniczą w jej życiu. O tym świadczą zachowania, takie jak: poczucie „inności”, zalogowanie się na portalu społecznościowym dla osób homoseksualnych, uczęszczanie do gejbaru. Na kształt świadomości grupowej gejów ogromny wpływ miał Internet. Egzemplifikację stanowią wypowiedzi badanych, które wskazują na spadek roli gejbaru jako czynnika integrującego toruńską grupę: jego rola ogranicza się do realizacji kontaktów, które zostały zawarte za pośrednictwem Internetu. Młodsi badani uważają, że podstawą ich istnienia w środowisku homoseksualnym jest właśnie Internet:

Jak sobie wyobrażasz relacje w grupie homoseksualistów bez Internetu? - Myślę, że takowych w ogóle by nie było. - Kontakty barowe wynikają przeważnie z netu. - Myślę, że gejbary są dopełnieniem kontaktów internetowych.

Z tych wypowiedzi może wynikać, że spada rola kontaktów interpersonalnych w klubach dla osób homoseksualnych, a znacznie wzrasta rola kontaktów przez nowe media. Ma to odzwierciedlenie w degradacji grupy, która skupia się w mniejszych, kilkuosobowych grupkach. Ponadto trzeba zauważyć, że świadomość grupowa może wynikać z samego faktu założenia profilu. Osoby czujące potrzebę przynależności do grupy logują 
się na danym portalu, zrzeszającym osoby homoseksualne. Zalogowanie wiąże ze sobą kolejne działania, jak przyznanie przed sobą samym, że jest się homoseksualistą, zaangażowanie się w działalność i życie grupy, czynny udział przez spotkania i wizyty w gejbarze.

Osoby homoseksualne pełnią funkcje społeczne przypisane członkom grupy. Są to przede wszystkim role funkcjonalne (celowe - związane z celem grupy), de facto seksualne. Rolą społeczną geja jest więc rola seksualna ukierunkowana na poszukiwanie partnera. Homoseksualista uczy się jej, dokonując fragmentaryzacji życia na obszary homoseksualne i te przynależne kulturze dominującej. Przy czym nie możemy mówić tutaj o całkowitym rozpadzie wcześniejszego modelu życia ani też o zastępowaniu wszystkich jego heteroseksualnych elementów elementami homoseksualnymi. Istotę zjawiska fragmentaryzacji trafnie ujął Jerzy Mikułowski-Pomorski w artykule Fragmentaryzacja w mediach: proces i narzędzie [2006]. Stwierdził on, że: „Fragmentaryzacja to nie zanik części dawnych całości, ich całkowity rozpad; to raczej trwanie ich części w pewnym stanie wyróżnialnym i rozpoznawalnym, zdolnym przez pewien czas samodzielnie funkcjonować". Nowe media dzięki swojej specyfice i powszechności przyciągnęły grono osób homoseksualnych, gdyż zaoferowały im możliwość owej fragmentaryzacji (podziału życia) przez zapewnienie anonimowości.

Bez odpowiedzi nie może pozostać pytanie o to, co inicjuje powstanie homoseksualnej społeczności wirtualnej. Podstawą istnienia każdej grupy są jej cele i potrzeby. Zdaniem Anu Wadhwa i Suresh Kotha [za: Szpunar 2004: 110] kanwę tworzenia się i trwania wirtualnych społeczności stanowią takie potrzeby, jak: komunikacja, informacja, rozrywka i transakcja. W przypadku grupy gejów potrzeby wymienione przez Wadhwa i Kotha należy uznać za drugoplanowe.

Poza nauką roli społeczność wirtualna gejów spełnia także pewne funkcje. Osoby udzielające wywiadu nie ukrywały, że ma ona przede wszystkim charakter seksualny. Pojawienie się nowych mediów wpłynęło znacząco na częstotliwość zmiany partnerów. Należy zwrócić tu uwagę, że w środowisku tym panuje promiskuityzm, co oznacza że częsta zmiana partnera nie wzbudza negatywnych emocji. Poza funkcją seksualną możemy wyróżnić funkcje psychospołeczne, w tym funkcję adaptacyjną. Badani często poszukiwali akceptacji i informacji przez czat, pocztę elektroniczną lub komunikatory internetowe. Można to nazwać nauką roli społecznej geja przez wymianę informacji. Cyberprzestrzeń i jej wpływ na hermetyczną grupę społeczną, jaką stanowią geje, pozwoliły na rozwinięcie się funk- 
cji emocjonalnej (zapewnienie potrzeby bezpieczeństwa, potrzeby przynależności do grupy, potrzeby akceptacji). W tym wypadku można mówić również o poszukiwaniu uczuć: miłości i przyjaźni, o czym świadczy wypowiedź jednego z badanych: „Założyłem je [profile na portalach gejowskich - przyp. aut.], bo zacząłem już myśleć o poważnym związku". Kolejną funkcją jest funkcja informacyjna. Respondenci w następujący sposób ją podkreślali: „Najbardziej się skupiałem na informacjach dotyczących chorób wenerycznych, HIV, AIDS. Co robić, żeby się nie zarazić, jak uprawiać bezpieczny seks - głównie takich informacji szukałem w Internecie". Można zatem stwierdzić, że Internet ma charakter edukacyjny [Lewandowski i in. 2011: 76].

\subsection{Internet a poczucie więzi}

Mówiąc o więzi społecznej, należy na wstępie wymienić jej podstawowe komponenty. Stanisław Kosiński [1987: 174] za części składowe więzi społecznej uważa: styczność przestrzenną (spotkania w gejbarze, spotkania, które są wynikiem znajomości zawartych w sieci), styczność i łączność psychiczną (którą zapewnia posiadanie konta, wymiana myśli, poglądów, przyjmowanie wzorców), styczność społeczną (wspólna mitologizacja świata, tworzenie własnych stereotypów), wzajemne oddziaływanie (wymiana poglądów, idei i myśli), wzory działań społecznych (wspólne akcje, prowokacje), stosunki, zależności, instytucje, kontrolę i organizacje.

Istnienie grupy jest gwarantem istnienia więzi wewnątrzgrupowej. Jak podaje Joanna Bierówka [2009: 119], homoseksualiści w wirtualnym świecie tworzą więź obiektywną, gdyż bycie gejem wyznacza pewien status, który determinuje do kultywowania tych samych opinii, zachowań i poglądów. Siłą kształtującą więź wewnątrzgrupową jest zasada wzajemności. Natomiast jej narzędzie stanowi nowe medium, jakim jest Internet. Zasada wzajemności to relacja zobowiązująca jednostkę do działania na rzecz innych osób przez wzgląd na ich wcześniejsze działania wobec niej, a nie cechy społeczne czy pozycje tych osób [Bierówka 2009: 18]. Zasada ta zakłada, że: „W relacjach międzyludzkich dostarczenie jednostce pewnego dobra czy wyświadczenie przysługi wyzwala w niej poczucie zobowiązania" [Bierówka 2009: 25]. Często określa się ją łacińskim zwrotem do ut des - "daję, żebyś dawał". Jako zasadę wzajemności możemy rozpatrywać w świecie wirtualnym budowanie tożsamości i wymianę doświad- 
czeń. Innym jej przykładem niech będzie wzajemne świadczenie usług seksualnych (taki profil mają portale grupujące homoseksualistów), co przypomina koncepcję zasady wymiany Petera Blaua [za: Bierówka 2007: 17]. Społeczność wirtualna osób homoseksualnych opiera się na strukturach wzajemnościowych relacji, określanych przez Bierówkę [2007: 27] posttradycyjnym communitas, które są budowane ponad przestrzennymi i kulturowymi ograniczeniami. Mają one charakter ekskluzywny, gdyż przynależność do nich zależy od preferencji seksualnych, akceptacji i stałego uczestnictwa w życiu wirtualnym, jak i realnym.

Do działania wspólnotowego należy zaliczyć communitas - wynikające z zasady wzajemności; są to działania emocjonalne, pozarefleksyjne. Zdaniem Bierówki [2009: 19]:

adaptuje się je z charakterystyczną dla siebie kreatywnością do zaistniałych okoliczności, wykorzystując w tym celu m.in. nowe techniki komunikacji (telefonię i Internet). Dzięki nim człowiek zaspokaja swoje psychospołeczne potrzeby, budując więzi wzajemnościowe (typu communitas) poza czasem i przestrzenią. Cyberprzestrzeń jest środowiskiem szczególnie sprzyjającym działaniu zasady wzajemności, a co za tym idzie, budowaniu communitas. Staje się ona zarówno platformą komunikacyjną dla communitas działających w realnym świecie, zainicjowanych w sieci lub poza nią, jak i dla communitas wirtualnych.

Przez communitas będziemy więc rozumieć wszelkie przejawy grupowania się na tym samym profilu, portalu. Są one celowe, gdyż wynikają z potrzeby seksualnej, emocjonalnej. Do działań wspólnotowych należy zaliczyć także prowokację, tzn. akcję mającą na celu demonstrację homoseksualnego stylu życia.

Kolejnym wartym odnotowania spostrzeżeniem jest fakt, że wszyscy homoseksualiści stawiają swoją orientację seksualną na równi z innymi orientacjami. Mamy w tym przypadku do czynienia z relatywizmem norm, czyli z przekonaniem, że nie ma ani gorszej, ani lepszej orientacji seksualnej. Jest to wypracowane wspólnie stanowisko w odniesieniu do określonej kwestii. Na taki stan rzeczy miały wpływ przemiany po 1989 roku, ale również nowe media, które dostarczają naukowych wyjaśnień i badań na temat homoseksualizmu.

Dodatkowo poczucia więzi dowodzi używanie przez rozmówców zwrotów: „my”, „nam”, „,nas”. Samo poczucie przynależności do grupy po- 
woduje pojawienie się myślenia w kategoriach „my" - „oni". Poczucie wspólnoty i silna identyfikacja z członkami zbiorowości wyrażona jest przez częste używanie zaimka „my", któremu towarzyszy świadomość odrębności od osób z zewnątrz. Zjawisko to jest przejawem tożsamości zbiorowej [Sztompka 2002: 198]. Można ją zauważyć we wspólnej wymianie doświadczeń, która dokonywała się na początku wchodzenia w homoseksualne role społeczne. Poczucie więzi to również wspólne odnoszenie się do stereotypów i stygmatyzacji społecznej. Więź funkcjonuje w istnieniu podziału na my - obcy, homo - hetero. Dystans społeczny oraz tendencje izolacyjne wpływają na poczucie odrębności i tym samym kształtowanie się więzi w grupie. Internet stał się narzędziem determinującym ową świadomość więzi. Dzięki niemu wielu toruńskich gejów zrozumiało, że nie są sami, że nie muszą być wyobcowani. Jeden z badanych w następujący sposób opisywał swoje odczucia z okresu, w którym nie miał jeszcze dostępu do Internetu:

To było tak, że ja zawsze miałem takie dzikie wrażenie, że jestem jedyną osobą na świecie, która powiedzmy tak myśli, która ma takie przemyślenia [...]. Nawet miałem w planach jechać do Warszawy, bo myślałem sobie: Boże, Toruń to takie małe miasto, że tutaj pewnie takie osoby w ogóle nie żyją. I tak strasznie dziwnie, samotno, obco.

Poczucie nietolerancji i pokrzywdzenia przez społeczeństwo wzmaga w członkach grupy potrzebę akceptacji i bezpieczeństwa, które także przekładają się na tworzenie więzi. Innym ich przejawem jest poczucie solidarności grupowej czy też wspomniana już prowokacja [Lewandowski i in. 2011: 41-42].

\section{Wpływ na jednostkę}

\subsection{Internet a jednostka}

Nowe media wpłynęły znacząco na zachowanie jednostek. Jednym ze skutków powstania Internetu stała się możliwość promowania homoseksualnego stylu życia. Jednostka, adaptując się do nowych warunków, przyjmuje świadomość grupową i zaczyna aktywnie uczestniczyć w życiu grupy. Wiąże się to z nauką roli społecznej, której wzorów dostarcza wie- 
dza zaczerpnięta z Internetu. Nowo powstała instytucja - związek partnerski - jest intensywnie promowana na portalach informacyjnych dla osób homoseksualnych. Ponadto cyberprzestrzeń wywiera wpływ także na zachowania seksualne. Jak trafnie zauważyła Marta Klimowicz [2006: 313]:

O ile geje starszej daty wciąż wspominają czasy, gdy w każdym mieście było określone miejsce, gdzie szło się na wspomniane już pikiety, często ryzykując aresztowanie przez milicję, to młodszemu pokoleniu homoseksualistów problem ten jest niemal zupełnie nieznany. Oni również mają swoje miejsce, do którego się udają, gdy chcą kogoś poznać - Internet.

Świat wirtualny pozwala na poznanie partnera i życie w parze, zaspokajając tym samym potrzeby emocjonalne. Wpływa również na zwiększenie liczby partnerów i częstotliwość ich zmian. Częstość takich rotacji jest ewidentnym skutkiem pojawienia się nowych mediów, które ułatwiają poszukiwania nowego partnera. Wcześniej, gdy grupa była nieliczna, zdobycie partnera odbywało się przez kontakt bezpośredni, za pomocą symboli i znaków charakterystycznych dla gejów. Obecnie jest to metoda zanikająca, a dzieje się tak za sprawą Internetu, który oferuje o wiele większy wachlarz możliwości.

Mark Smith [1992: 108] wyróżnił pięć podstawowych cech społeczności wirtualnej, które nie mają egzemplifikacji w świecie fizycznym. Są to: aprzestrzenność, asynchroniczność, acielesność, astygmatyczność i, najistotniejsza z punktu widzenia niniejszego artykułu, anonimowość. Jest ona jedną z wartości, jakie niosą ze sobą nowe media. To ona jest bodźcem dla osób homoseksualnych do założenia profilu na portalu gejowskim. Anonimowość Internetu jest równoznaczna z bezpieczeństwem, o które bywa trudno w świecie rzeczywistym. Najbardziej świadomi tego są badani w starszym wieku. Natomiast młodsi doceniają alternatywę, jaką zaoferował im Internet. Jeden z uczestników twierdzi, że: „Różnie bywało z tymi pikietami. Można było pójść, można było dostać w mordę, można było zostać spisanym przez policję. Jednak Internet mimo tej otwartości ma tę przewagę, że jest o wiele bezpieczniejszy niż taka pikieta". Anonimowość oraz poczucie większego bezpieczeństwa wpływają na okres samookreślenia orientacji seksualnej. Osoby młode (do 25 roku życia) stanowią 65\% użytkowników portali internetowych dla gejów [Lewandowski i in. 2011: 44]. 
Następująca wypowiedź sygnalizuje kolejną zmianę, którą środowisko homoseksualne zawdzięcza cyberprzestrzeni: „Internet to był jedyny mój element w życiu, dzięki któremu mogłem z kimś o tym porozmawiać, kogoś poznać. Ja jestem ze wsi i u mnie we wsi nie ma drugiej takiej samej osoby jak ja". Dotychczas geje pochodzący z małych miejscowości lub wsi byli z góry skazani na migrację do dużych ośrodków miejskich. Powody bywały co najmniej trzy. Po pierwsze, lęk przed społecznym ostracyzmem, po drugie, lęk przed krytyką rodziny i najbliższego środowiska, a po trzecie, brak możliwości poznania potencjalnego partnera. Internet dał alternatywę homoseksualistom, pochodzącym z małych społeczności. Zatem można stwierdzić, że na proces samookreślenia miał wpływ dostęp do Internetu [Lewandowski i in. 2011: 45].

\subsection{Internet a zjawisko coming out}

Zmiany, jakie niosą ze sobą nowe media, są związane ze skróceniem czasu inicjacji homoseksualnej. Przede wszystkim chodzi tutaj o dochodzenie do coming outu. Coming out to ujawnienie swojej orientacji najbliższemu otoczeniu. Naukowo udało się przyjąć przebieg owego procesu. Rozpoczyna się on od „jednostki, która nie jest świadoma swojej homoseksualnej orientacji i często podziela powszechne poglądy, że bycie homoseksualistą jest degradujące, potępiane lub co najmniej traktowane jako inność. Kończy się zaś akceptacją swej seksualności, uznaniem jej przez siebie i przez innych" [Majka-Rostek 2002: 158]. Przyjmując pogląd wspomnianej badaczki, należy pamiętać, by odnieść go do homoseksualistów w starszym wieku. Właśnie u tych osób występował ów klasyczny model coming outu.

Jak wynika z badań przeprowadzonych na potrzeby niniejszej pracy, w czasie ostatnich kilku lat nastąpiła zmiana schematu ujawniania się. Zbliża się on do sześciu faz zaproponowanych przez C. L. Adamsa i D. C. Kimmela: tożsamościowy nieład, porównanie, tolerancja, akceptacja, duma, synteza, integracja [za: Majka-Rostek 2002: 159]. Odnosząc się do owego modelu, należy wskazać przebieg dochodzenia do tożsamości młodszych rozmówców (w wieku 22-28 lat), gdyż oni najlepiej reprezentują powyższy model [Lewandowski i in. 2011: 71]. Potwierdzeniem niniejszego stwierdzenia niech będą wyniki badań przeprowadzonych przez prof. Izdebskiego [za: Czupryn 2009: 1-2] na grupie 400 mężczyzn w wieku od 
19 do 50 lat. Mężczyźni zadeklarowali wcześniej odbywanie stosunków seksualnych z innymi przedstawicielami swojej płci. Wyniki kształtowały się następująco: 86\% mężczyzn potwierdziło, że przeszło już coming out, przy czym aż 65\% z nich jest w wieku 16-25 lat, a 12\% (jeden na ośmiu przebadanych) uczynił to już przed ukończeniem 15 roku życia. Wynika z tego, że od wczesnych lat młodości zdawali sobie sprawę ze swej nieheteroseksualnej orientacji. Niewątpliwie w dużej mierze jest to zasługą Internetu, który oferował im dostęp do informacji bez uczucia wstydu, a także umożliwiał wymianę przemyśleń i obaw. Młodzi rozmówcy w Internecie poszukiwali innych homoseksualistów, z którymi porównywali swoje doświadczenia i przeżycia. Zdawali sobie sprawę ze swojej odmienności, ale nie potrafili jej jeszcze uzasadnić albo zdefiniować. Samoakceptacja przychodziła zazwyczaj wraz z pierwszymi kontaktami z innymi gejami. Posługiwanie się Internetem w kontaktach towarzyskich nie jest tylko domeną młodych homoseksualistów, ale to oni przeważają. Ponad $92 \%$ z nich to osoby przed 35 rokiem życia. Najliczniejszą grupą wiekową jest grupa osób w wieku 20-25 lat. Nie jest to bez znaczenia, gdyż właśnie w tym okresie najczęściej dochodzi do samoakceptacji. Istotny jest również fakt, że do Torunia napływa wiele młodych osób z tego przedziału wiekowego w celu podjęcia studiów [Lewandowski i in. 2011: 71].

Obok zjawiska coming out mamy do czynienia ze zjawiskiem closing in - zamknięciem w grupie i w świadomości grupowej [Lewandowski i in. 2011: 41]. Osoba taka nie ma doświadczenia związanego z obcowaniem w grupie, nie jest jeszcze pewna jej obecności w świecie rzeczywistym. Kontaktując się z użytkownikami portali dla gejów, osoba doświadczająca zjawiska closing in stara się odpowiedzieć sobie na pytania dotyczące własnej orientacji seksualnej. Założenie profilu na portalu gejowskim jest jedną z prób poszukiwania siebie, jak określa to jeden z badanych:

Wówczas potrafisz określić siebie jako geja i ujawnić się na stronie. Poza tym przez sam profil sam siebie określasz. On chyba w tym nawet pomaga.

Dlatego możemy wnioskować, że założenie profilu jest etapem do świadomej akceptacji siebie jako homoseksualisty.

Część badanych zakładała swój profil dopiero po pierwszych kontaktach i związkach z inną osobą homoseksualną. W ich wypadku było to wynikiem świadomej akceptacji siebie i poszukiwaniem innych. Ponieważ 
profil nastawiony jest na funkcje towarzyskie, poszukiwanie siebie może odbywać się tu przez poszukiwanie innych. Podobnie jak określenie się mężczyzny przebiega poprzez odróżnienie się od kobiety [Domański 2005: 32-33], tak homoseksualista z braku naturalnego wzorca do odróżnienia swojej orientacji poszukuje innego homoseksualisty, który stanowi dla niego miarę i punkt odniesienia.

Kiedy następuje pogodzenie $z$ własną orientacją seksualną? Jest to pytanie, na które nie można udzielić jednoznacznej odpowiedzi. Pogodzenie się z własną orientacją jest kwestią indywidualną. Jak wykazały wywiady z naszymi rozmówcami, pogodzenie - nazwanie samego siebie gejem, akceptacja - następuje w różnym okresie w życiu. Przeważnie jest to okres od początku dojrzewania płciowego, np. od 13 roku życia do lat dojrzałej młodości. Zazwyczaj kończy się około 20 roku życia i przynosi ze sobą wejście w pierwsze dojrzałe związki homoseksualne.

\subsection{Internet a samoidentyfikacja}

Istotną kwestią są zmiany w procesie przechodzenia od samoidentyfikacji negatywnej do samoidentyfikacji pozytywnej. Zmiany te są spowodowane powstaniem nowych mediów. Poruszając kwestie samoidentyfikacji, warto przytoczyć teorię Arnolda van Gennepa [2006: 35-36]. Zauważył on, że proces godzenia się z własną orientacją przejawia się w trzech „rytuałach przejścia" - rytuale rozłąki, oczekiwania oraz integracji [za: Majka-Rostek 2001: 179-190].

Rytuał rozłąki swoją nazwę zawdzięcza procesowi rozłączenia się ze swoją pierwotną tożsamością. Najpierw chłopiec odróżnia się od świata kobiet, określa swoje cechy, widzi rolę mężczyzny jako męża i ojca. Następnie uświadamia sobie, że jego pociąg seksualny jest ukierunkowany na mężczyzn, a co za tym idzie - wszystkie oczekiwania, jakie wiąże z nim społeczeństwo, nie będą mogły być spełnione. Budzi to wewnętrzną i często moralną sprzeczność. Homoseksualista doświadcza wręcz rozpadu tożsamości pierwotnej, co buduje w nim napięcie, uczucie strachu i ogólną dezorientację. Chcąc zwalczyć te uczucia, osoba homoseksualna za wszelką cenę chce powrócić do sytuacji początkowej, dobrze już znanej. Próbą ochrony tożsamości pierwotnej jest postawa typu: „jestem taki jak inni". Następuje silne wyparcie swojego prawdziwego ja - jest to samoidentyfikacja negatywna. Uczucie zaprzeczenia połączone z poczuciem 
inności, wyobcowaniem oraz samotnością są typowe dla etapu samoidentyfikacji negatywnej. Potęguje je brak informacji. Po rytuale rozłąki następuje rytuał oczekiwania. Osoba homoseksualna nie potrafi sobie poradzić z negatywnymi uczuciami i dąży do ich zredukowania przez poszukiwanie wiedzy na temat homoseksualizmu. Znalezienie tej wiedzy kończy etap wyobcowania, a zatem i etap samoidentyfikacji negatywnej. W tym miejscu docieramy do przemian, jakie zapoczątkowały nowe media. W czasach przed pojawieniem się Internetu źródłem informacji było środowisko heteroseksualne. Brak samoakceptacji pogłębiały negatywne stereotypy dotyczące homoseksualistów. To wszystko w sposób bezpośredni przekładało się na dość długi okres od momentu uzyskania świadomości homoseksualnej do pierwszych informacji na ten temat. Nowe media zrewolucjonizowały ów proces, znacznie go uprościły i przyspieszyły. Współcześnie następuje albo płynne przejście od etapu samoidentyfikacji negatywnej do samoidentyfikacji pozytywnej, albo całkowite pominięcie tej pierwszej [Majka-Rostek 2001: 186].

Zjawisko samoidentyfikacji pozytywnej, czyli umacnianie nowej tożsamości, jest cechą ostatniego Gennepowskiego rytuału - rytuału integracji. Nowe media stanowią kluczowy jego element. Przez kreowanie pozytywnego wizerunku geja budują przekonanie o relatywizmie norm. Jest to pogląd, według którego nie można określić normalnej orientacji, gdyż to, co jest normalne, jest czymś względnym.

Ciekawym zagadnieniem jest właśnie pojęcie dumy gejowskiej. By zbadać, czy istnieje takie zjawisko, zadawano pytanie: czy ukrywasz swoją orientację? Padały odpowiedzi następujące:

Byłem po prostu inny, też na swój sposób dziwny i ja to od samego początku traktowałem jako swoją siłę [...]. To, że jestem inny, czyni mnie nawet lepszym, bo nie jestem jakimś tam zwykłym, szarym człowieczkiem, tak? Tylko po prostu jestem kimś, kogo można wyróżnić z tłumu. Jestem kimś, kto może wyjść przed ten szereg i ja zawsze byłem z tego dumny tak naprawdę.

Osoby w wieku 22-28 lat nie starają się jej ukrywać, wręcz przeciwnie, niemal emanują swoją odmiennością seksualną, potrafią żartować ze swoich doświadczeń seksualnych. Zapewne wiąże się to z ich publiczną emanacją w gejbarze oraz z zaakceptowaniem siebie. Wpływ na to mają nowe media, które niosą za sobą poczucie więzi grupowej i poczucie bez- 
pieczeństwa. Poza tym badani odczuwają istnienie alternatywy dla społeczeństwa heteroseksualnego w grupie homoseksualistów. Osoby starsze ukrywają swoją orientację z obawy przed społeczeństwem i jego nietolerancją. Nie mają dostatecznego poczucia więzi z grupą ani nie mogą pozwolić sobie na utratę pozycji, jaką zajmują obecnie w społeczeństwie [Lewandowski i in. 2011: 65]. Wspomniane już badania przeprowadzone przez prof. Izdebskiego [za: Czupryn 2009: 1-2] potwierdziły to zjawisko: między 25 a 30 rokiem życia do swej orientacji przyznało się zaledwie $6 \%$ badanych, a po 30 roku życia tylko $2 \%$. Natomiast $13 \%$ homoseksualistów nie powiedziało o swych skłonnościach nikomu ze swojego otoczenia. Wniosek zatem jest prosty - im gej jest starszy, tym trudniej przychodzi mu dokonanie coming outu.

\subsection{Internet a dystans poznawczy}

Osoby homoseksualne zdają sobie sprawę ze swej odrębności. Posługują się dystansem poznawczym polegającym na postrzeganiu różnic między własną grupą a grupą innych. Im więcej członkowie dostrzegają owych różnic, tym ten dystans jest większy. W niniejszych badaniach można wyróżnić trzy rodzaje dystansu poznawczego.

Pierwszym z nich będzie dystans „do siebie", który prezentują osoby starsze. Osoby te nie dokończyły w okresie dojrzewania procesu dochodzenia do tożsamości osobistej, oceniają się w kategoriach „inny". Ponadto reprezentują również drugi rodzaj dystansu - dystans "do grupy". Taki sam dystans uwidacznia się w przypadku najmłodszego badanego, który nie bierze udziału w życiu grupy bezpośrednio, posługuje się zaś wyłącznie Internetem. W kontaktach z innymi homoseksualistami twierdzi, że jest spoza środowiska. Osoby tego typu nie identyfikują się z grupą, nie uczestniczą aktywnie w jej funkcjonowaniu, niemniej samoidentyfikują się jako osoby homoseksualne [Lewandowski i in. 2011: 67].

Pozostali rozmówcy otwarcie określają siebie mianem gejów lub homoseksualistów. Są to osoby reprezentujące dystans „do innych". Przejawia się on jako dystans "do innych pedałów" lub do innych - jako osób heteroseksualnych. Osoby te są aktywne w środowisku grupy, funkcjonują aktywnie w nowych mediach oraz są stałymi bywalcami gejbarów. Ich dystans odnosi się do członków społeczeństwa, wyrażającego nietolerancję. Dystans uwypuklają nowe media. W tym przypadku mamy 
do czynienia z dwoma podejściami do dystansu: jego niwelowaniem, które reprezentuje Replika.pl, homiki.pl, przez traktowanie w swych artykułach osób homoseksualnych na równi z heteroseksualistami, oraz z podejściem sceptycznym, reprezentowanym przez portale społecznościowe, które zawierają różne formy sprawdzenia, czy dana osoba jest spoza środowiska, i możliwość jej wykluczenia. Dystans jest podkreślany na wszystkich tych stronach przez posługiwanie się symboliką barw i kolorów. Zwłaszcza na portalach informacyjnych spotykamy często kolory tęczy, które są symbolem homoseksualnego ruchu [Lewandowski $i$ in. 2011: 67-68].

Innym przejawem dystansu jest chęć zachowania anonimowości i nieujawnianie się jako osoba homoseksualna. Owa anonimowość jest dobrze widoczna na portalach, na których osoby homoseksualne posługują się nickami. Także w życiu codziennym i w jego homoseksualnej sferze geje posługują się pseudonimami. Są to pseudonimy niewywołujące wątpliwości co do oryginalności i wiarygodności, jednak kamuflujące prawdziwe dane osobowe.

Czy homoseksualiści są społecznością otwartą, czy zamkniętą? Pytanie to dotyczy dystansu behawioralnego. Można na nie odpowiedzieć, analizując tendencje izolacyjne, czyli mniejszą lub większą chęć rozmówców do nawiązywania kontaktów z heteroseksualistami. Większość badanych deklarowała, że ma znajomych oraz przyjaciół zarówno w środowisku homoseksualnym, jak i heteroseksualnym. Niektóre osoby przejawiały jednak tendencje izolacyjne. Większość zaś uważa, że homoseksualiści nie stanowią dominującej grupy ich znajomych i raczej nie widzi się tylko w tej grupie. Rozmówcy dokonują wspomnianej wcześniej fragmentaryzacji życia, jak i wybiórczej deklaratywności, czyli ujawnienia się przed wybranymi członkami społeczeństwa (w gronie przyjaciół, znajomych).

Badani uważają ponadto, że homoseksualiści są grupą zamkniętą, która komunikuje się w swoim obrębie za pomocą nowych mediów. W tym wypadku należy zauważyć, że informacje krążą w modelu zamkniętego koła. Informacje dotyczą życia grupy, mała jest rola informacji z zewnątrz i informacji ogólnych. Wskazuje to na tendencję izolacyjną pod względem pozyskiwania i przekazywania informacji [Lewandowski i in. 2011: 68-69]. 


\subsection{Internet a tożsamość}

Powstanie Internetu możemy rozpatrywać pod kątem kształtowania się tożsamości. Alicja Borasińska [2009: 43] w następujący sposób ją definiuje: „Tożsamość bowiem nie jest regularną całością, a procesem, ciągłym stawaniem się - zróżnicowanym i fragmentarycznym". Jednostka, zanurzając się w cyberprzestrzeni, za każdym razem może w inny sposób modyfikować swoje dane, takie jak: wiek, imię, wygląd, zawód, wykształcenie. W łatwy sposób może stać się taką osobą, jaką zawsze chciała być. Zjawisko to doskonale opisuje właśnie Borasińska [2009: 38]: „Tym samym podmiot ma sposobność izolowania się w stosunku do tożsamości, z którą funkcjonuje w świecie fizycznym, modelować ją, potęgować, ulepszać niektóre jej aspekty bądź eliminować te, których nie akceptuje w świecie fizycznym". Anonimowość Internetu oraz jego acielesność gwarantują jednostce komfort bezpieczeństwa. W ten sposób świat wirtualny oferuje jej coś, czego rzeczywistość nie jest w stanie zrobić - bezkarne wypróbowanie różnych tożsamości. Dochodzi tutaj do zjawiska switchingu, które polega na zmianie lub zamianie osobowości. Jego przyczyn można upatrywać w stereotypach występujących w społeczeństwie. Ponadto wyznacznikami „mogą być wstyd, zakłopotanie, cyberpoprawa statusu społecznego czy po prostu chęć doświadczenia innych tożsamości i ekspresja, ukrywanych w świecie realnym, atrybutów osobowości" [Borasińska 2009: 39-40]. Właśnie takie zachowania dominowały wśród osób homoseksualnych. Geje - jako ofiary funkcjonujących w społeczeństwie stereotypów, odnaleźli się w odizolowanym, hermetycznym cyberświecie, który pozbawiony jest prześladowań i uprzedzeń. Budowa tożsamości seksualnej w Internecie jest nowym zjawiskiem, które zostało przez nas zaobserwowane.

Należy rozróżnić trzy rodzaje tożsamości: osobistą, społeczną oraz kulturową. W pierwszym przypadku $w$ trakcie badania ocenie podlegał sposób, w jaki rozmówcy mówili o sobie, identyfikowali siebie oraz kiedy identyfikacja ta następowała. Z przeprowadzonych wywiadów wynika, że nowe media miały znaczący wpływ na tożsamość osobistą. Część rozmówców, która w latach dojrzewania nie miała dostępu do Internetu, znacząco później dochodziła do swojej tożsamości, mówiąc o sobie w kategoriach „inny”. Pozostali rozmówcy dochodzili do swojej tożsamości w kontaktach i rozmowach z innymi homoseksualistami. Pierwotnie jednak często czerpali informacje ze świata heteroseksualnego, który ich otaczał, oraz ze stereotypów funkcjonujących w społeczeństwie. Dostęp do Internetu po- 
zwolił na wejście w interakcje, na porównania, na wymianę doświadczeń, które przełożyły się na budowę tożsamości osobistej. Wiąże się to również z podejściem do świata zewnętrznego i ze zjawiskiem coming out [Lewandowski i in. 2011: 60].

Kolejny rodzaj tożsamości - tożsamość społeczna pozytywna, okazywana jest przez faworyzowanie własnej grupy wśród rozmówców. Niektórzy zamykają się w grupie homoseksualistów, dla innych zaś homoseksualiści stanowią liczną grupę znajomych. Jednak nie faworyzują swojej orientacji w pojedynkę, gdy już ma do tego dojść, dzieje się tak za sprawą prowokacji.

Tożsamość kulturową widać zaś w zachowaniu i ubiorze naszych respondentów, którzy ubierają się na styl „stereotypowego geja”. Potrafią oni wyszczególnić typowe dla tego stylu elementy. Jak to określa jeden z badanych:

Jeśli chodzi o ubiór, to oczywiście irokeziki, irokeziki obowiązkowo. No i kolczyki, tak irokeziki i kolczyki. Ja kolczyki też miałem, ale teraz akurat powyciągałem. U mężczyzn hetero obcisłe ubrania noszą tylko mężczyźni dobrze zbudowani, natomiast jeśli mężczyzna nie jest dobrze zbudowany, to można przypuszczać, że jest gejem. I przeplatanie takich rzeczy damskich, np. rzemyki, koraliki, szaliczki, apaszki, kolory różne, dzwony. Jak miałem 16 lat, to też latałem w dzwonach. Poza tym jeśli widzę chłopaka w rurkach, wielki gruby szal, więc stwierdzam, że jest gejem. Większość ludzi, którzy tak się ubierają, są gejami. - Oczywiście gestykulacja, wyraz twarzy, maniery, zwyczaje typowe dla kobiet. Często dochodzi do tego też specyficzna mowa. To są cechy stereotypowego geja, które są przez część z nas kultywowane.

Ponadto część homoseksualistów ma podobny stosunek do Kościoła katolickiego i większość z nich preferuje przyjęty w grupie model monogamisty z częstą skłonnością do zmian. Gdyby posłużyć się terminologią tożsamości homoseksualnej, stworzoną przez Jacka Kochanowskiego [2004: 157-159], tożsamość gejów rozumiana byłaby przez nas i rozpoznawana wówczas, gdy dana osoba sama określałaby się takimi pojęciami, jak: gej, homoseksualista. Pojawiają się również pojęcia typu „pedał”, które także świadczą o tożsamości, ale negatywnej (w tym wypadku zazwyczaj ukierunkowanej w stronę innych). Nowy sposób komunikowania przyczynił się do zmiany sposobu postrzegania wzajemnego przez przeniesienie postrzegania jednostkowego (jaki jestem ja, tacy są inni) na po- 
strzeganie grupowe (jacy są inni, taki jestem ja). Zmiana niby niewielka, ale przyniosła ze sobą wiele skutków. Po pierwsze, mamy do czynienia ze zmianą w tożsamości oraz ze zmianą związaną z okresem dochodzenia do samookreślenia jej. Po drugie, jest to włączenie myślenia grupowego (my, nas, nam). Po trzecie, to zauważalne włączenie tendencji izolacyjnych (odróżniających nas od nich). Po czwarte, integralność grupy, czyli postrzeganie siebie w relacjach z innymi osobami zarówno hetero-, jak i homoseksualnymi. Najważniejszą jednak zmianą jest postrzeganie grupowe (nawet masowe), które było zjawiskiem obcym przed pojawieniem się Internetu [Lewandowski i in. 2011: 59].

\section{Wpływ na komunikację}

Pojawienie się nowych mediów zrewolucjonizowało dotychczasową strukturę komunikacji. Jak wynika z przeprowadzonych analiz, można stwierdzić, że komunikowanie przeniosło się w świat wirtualny. Przede wszystkim pojawił się nowy kanał przekazu: Internet, oferujący szeroki wachlarz możliwości. Spowodowało to niekontrolowany rozrost grupy, łatwiejszy przepływ informacji, nową możliwość grupowania się, przyspieszenie przekazu informacji oraz centralizację jej źródła. Pierre Levy [2005: 386-387] wyszczególnił następujące korzyści, jakie niesie ze sobą upowszechniona łączność oraz digitalizacja informacji:,,zanik monopolu przekazu publicznego; rosnąca różnorodność sposobów ekspresji; rosnące możliwości sprzętu umożliwiającego poruszanie się wśród zalewających nas informacji i ich odsiew; rozwój wirtualnych wspólnot i międzyludzkich kontaktów na odległość w poszukiwaniu zaspokojenia wspólnych zainteresowań".

Prawdą jest, że homoseksualiści chętnie odwiedzają czaty internetowe (specjalne miejsca w cyberprzestrzeni, w których w czasie rzeczywistym można porozmawiać). Jak zauważa w swych badaniach Marta Klimowicz [2006: 310]: „Możliwe, że jedyną, choć z pewnością niezwykle istotną różnicą między czatami heteroseksualistów a gejów jest większa bezpośredniość tych drugich". Dodatkowym, bezpośrednim efektem Internetu stały się zorganizowane zloty osób homoseksualnych - uczestników czatów. Toruńskie zloty tak opisuje jeden z badanych:

A jak były te zjazdy, to spotykaliśmy się właśnie w takim klubie, ktoś tam załatwiał wcześniej imprezę, wszyscy przychodzili i zaczynało się zga- 
dywanie, kto jest kto. Ludzie mieli swoje nicki, ja na przykład miałem nick Toruń17, i się zaznajamiali. Trochę też się piło, trochę tańczyło, rozmawiało i bawiło. Wymieniało się tymi wszystkimi rozmowami, przeżyciami i doznaniami. Były tam osoby w różnym wieku. Tak naprawdę to się to wszystko po prostu chłonęło, tak ja to pamiętam. To właśnie mnie wciągnęło, bo wcześniej nie miałem okazji uczestniczyć w takim życiu, a chciałem już od dawna. Nagle zobaczyłem, że za tym magicznym oknem monitora istnieje jednak taki świat, że ludzie tacy istnieją, to po prostu strasznie fajne było dla mnie.

Powyższa wypowiedź zaprzecza słowom Patricii Wallace [2001: 198], która w książce Psychologia Internetu napisała, że: „Częściej jednak związek nigdy nie wykracza poza sieć i między partnerami nie dochodzi nawet do rozmowy telefonicznej, toteż sieciowa osobowość jest wszystkim, czym dysponujemy". Przyczyną odejścia od tejże reguły jest specyfika wirtualnej społeczności gejów, a przede wszystkim nastawienie jej na osiągnięcie określonych celów (głównie seksualnych). Zatem psychologia użytkowników Internetu - osób homoseksualnych, przejawiająca się w innym sposobie budowania relacji oraz emanacji świata wirtualnego na świat rzeczywisty, jest odmienna (wręcz odwrotna) od psychologii użytkowników Internetu - osób heteroseksualnych.

Warto podkreślić, że nowe media przejęły poważną część komunikowania bezpośredniego i przeniosły ją w świat wirtualny. Komunikowanie obecnie spełnia dwie zasadnicze funkcje: informacyjno-organizatorską i motywacyjno-inspirującą [Turowski 2001: 97-102]. Pierwsza polega na przekazywaniu informacji poziomowo (w naszym przypadku od instytucji KPH, SPR). Jak sprawdzono, respondenci otrzymywali informacje od tych instytucji o organizowanej prowokacji lub akcji mającej na celu powszechne wzbudzenie akceptacji i tolerancji dla wszystkich orientacji seksualnych. Były to również informacje pochodzące z czasopism i e-gazet. Informacje przekazywane $w$ ten sposób są znane badanym, jednak nie cieszą się wśród nich popularnością.

Podczas badania większą uwagę skupiono na drugiej funkcji komunikowania - motywacyjno-inspirującej. Jej rola polega na wytworzeniu w członkach grupy zaangażowania i współpracy, ale także na zapewnieniu wymiany informacji, myśli i przekonań pomiędzy jej członkami. Funkcja ta jest widoczna w pytaniu o hermetyczność i specyfikę grupy. Informacje te są powszechnie potrzebne i absorbujące odbiorcę, gdyż 
często dotyczą istotnych spraw (AIDS, HIV, sytuacji w grupie, relacji między członkami grupy). Internet oddziałuje także na popularyzację życia osób homoseksualnych. O ile wcześniej było ono zjawiskiem marginalnym, o tyle dzięki nowym mediom nabrało wymiaru masowego nie tylko miejskiego, lokalnego, ale też międzymiastowego [Lewandowski i in. 2011: 57].

Osoby homoseksualne funkcjonują w nowych mediach jako grupa społeczna. Należy jednak zauważyć, że pojawienie się Internetu wpłynęło dwojako na ową grupę: destruktywnie - przez zachwianie jej struktury w wyniku zwiększenia liczby jej członków, oraz konstruktywnie - przez zwiększenie świadomości grupowej. Mamy zatem do czynienia ze słabą grupą, a silną świadomością grupową toruńskich homoseksualistów.

Ponadto korzystanie $z$ Internetu wywołało rewolucję w procesie komunikacji grupy homoseksualistów w Toruniu. Wszelkie kontakty związane z pierwotnym coming outem, z integralnością i z dochodzeniem do tożsamości zostały przeniesione ze środowiska klubowego w świat wirtualny. Ten proces obrazują opinie naszych rozmówców, dla których gejbar to miejsce realizacji kontaktów zawartych za pośrednictwem Internetu na „neutralnym gruncie". W wyniku przeprowadzonych wywiadów zaobserwowano, że osoby starsze doceniają rolę sieci w kontaktach, ale pamiętają funkcjonowanie grupy bez Internetu, więc nie wyolbrzymiają jego znaczenia. Osoby w wieku 22-28 lat dochodziły do swojej tożsamości zarówno przez kontakt bezpośredni, jak i pomoc, której dostarczały im nowe media. Osoby młodsze nie widzą potrzeby wejścia w życie grupy w sposób bezpośredni. Komunikują się jedynie za pomocą sieci [Lewandowski i in. 2011: 72].

\section{Podsumowanie}

Nie można mieć najmniejszych wątpliwości co do ogromnej wagi zmian, jakie niesie ze sobą Internet. Wpłynął on przede wszystkim na małe, nieliczne dotąd grupy, które dzięki nowemu medium mogły zaistnieć i zacząć funkcjonować na szeroką skalę. Tak właśnie stało się z osobami homoseksualnymi, wokół których w społeczeństwie istnieje wiele przesądów i szkodliwych stereotypów, uniemożliwiających realne funkcjonowanie grupy. Internet stał się dla nich alternatywą. Pozwolił wyzwolić w cyberświecie skrywane preferencje seksualne. Zmiana w środowisku 
osób homoseksualnych nastąpiła jednak wcześniej. Pierwsze symptomy przemian pojawiły się po zmianie ustroju, następne zaś po pojawieniu się Internetu. Właśnie wówczas rozpoczął się nagły rozrost grupy, co miało duże znaczenie dla dalszego jej funkcjonowania i działania jej członków. Po pierwsze, nastąpił znaczny wzrost świadomości grupowej. Po drugie, osoby homoseksualne grupujące się w Internecie połączyły wspólne cele, które wynikają z ich homoseksualnej natury. Po trzecie, wytworzyło się poczucie więzi grupowej oraz dystansu do świata zewnętrznego - heteroseksualnego. Niemniej Internet wywarł istotny wpływ na jednostki w obrębie omawianej grupy. Anonimowość skłania gejów do ujawniania się bądź też poszukiwania innych osób homoseksualnych w tymże świecie. Tym samym dochodzi do fragmentaryzacji życia homoseksualisty, który swoją seksualność ujawnia najpierw w cyberprzestrzeni. To zjawisko z kolei łączy się z poczuciem więzi grupowej i brakiem osamotnienia, dzięki czemu osobie homoseksualnej łatwej dokonać coming outu. Da się przy tym zauważyć pewną rytualność zachowań i przejść przez kolejne stadia budowania własnej tożsamości. Homoseksualiści grupujący się w Internecie są przykładem wirtualnej społeczności, którą John Hegel i Arthur Amstrong określają jako społeczność relacji [Szpunar 2004: 110], ponieważ dzięki Internetowi tworzą i podtrzymują osobiste więzi z innymi członkami grupy.

\section{Bibliografia}

Bierówka Joanna. 2007. Internet jako źródło postaw prospołecznych.„Studia Socjologiczne" 3 (186).

Bierówka Joanna. 2009. Zasada wzajemności w społeczeństwie informacyjnym. Kraków: Krakowskie Towarzystwo Edukacyjne - Oficyna Wydawnicza AFM.

Borasińska Alicja. 2009. Nowe media - (nowa) psychologia odbiorcy. [W:] M. Jeziński (red.). Nowe media a media tradycyjne: prasa, reklama, Internet. Toruń: Wydawnictwo Adam Marszałek.

Domański Henryk. 2005. Tożsamość w świetle faktów. „Res publica nova” 3, R. 18.

Gennep Arnold van. 2006. Obrzędy przejścia: systematyczne studium ceremonii: o bramie i progu, o gościnności i adopcji. Warszawa: Państwowy Instytut Wydawniczy.

Klimowicz Marta. 2006. Connecting to reality - polscy geje w Internecie. [W:] Ł. Jonak, P. Mazurek, M. Olcoń, A. Przybyłska, A. Tarnowski, J. M. Zając (red.). Re:In- 
ternet - społeczne aspekty medium. Polskie konteksty i interpretacje. Warszawa: Wydawnictwa Akademickie i Profesjonalne.

Kochanowski Jacek. 2004. Fantazmat zróżnicowany. Socjologiczne studium przemian tożsamości gejów. Kraków: Universitas.

Kosiński Stanisław. 1987. Socjologia ogólna, zagadnienia podstawowe. Warszawa: Wydawnictwo Naukowe PWN.

Levy Pierre. 2005. Drugi potop. [W:] M. Hopfinger (red.). Nowe media w komunikacji społecznej wXX wieku. Warszawa: Oficyna Naukowa.

Lewandowski Piotr, Kobylska Joanna, Stanisławska Ewelina, Rakowska Agata, Szymborska Agata, Zblewska Magdalena. 2011. Wpływ nowych mediów na kształtowanie się relacji w grupie homoseksualistów w Toruniu. Niepublikowana praca badawcza studentów II roku Dziennikarstwa i Komunikacji Społecznej Uniwersytetu Mikołaja Kopernika w Toruniu.

Lew-Starowicz Zbigniew. 1999. Homoseksualizm. Warszawa: Wydawnictwa Lekarskie PZWL.

Loska Krzysztof. 2001. Dziedzictwo McLuhana - między nowoczesnością a ponowoczesnościq. Kraków: Rabid.

Majka-Rostek Dorota. 2001. Kreowanie tożsamości społecznej homoseksualistów jako proces przejścia od identyfikacji negatywnej do pozytywnej. „Kultura i Społeczeństwo" 2, R. 45.

Majka-Rostek Dorota. 2002. Mniejszość kulturowa w warunkach pluralizacji: socjologiczna analiza sytuacji homoseksualistów polskich. Wrocław: Wydawnictwo Uniwersytetu Wrocławskiego.

Szpunar Magdalena. 2004. Społeczności wirtualne jako nowy typ społeczności - eksplikacja socjologiczna. „Studia Socjologiczne” 2 (173).

Sztompka Piotr. 2002. Socjologia. Analiza społeczeństwa. Kraków: Znak.

Turowski Jan. 2001. Socjologia: małe struktury społeczne. Lublin: Towarzystwo Naukowe Katolickiego Uniwersytetu Lubelskiego.

Wallace Patricia. 2001. Psychologia Internetu. Poznań: Rebis.

\section{Źródła internetowe:}

Czupryn Anita. 2009. Polscy geje nie ukrywają się przed homofobami. http://www. polskatimes.pl/stronaglowna/79432,polscy-geje-nie-ukrywaja-sie-przedhomofobami,id,t.html?cookie=1\#material_2, 2.01.2011.

Mikułowski-Pomorski Jerzy. 2006. Fragmentaryzacja w mediach: proces i narzędzie. „Global Media Journal - Polish Edition” 1, Spring. http://www.global- 
mediajournal.collegium.edu.pl/artykuly/wiosna\%202006/Mikulowski\%20 Pomorski\%20-\%20Fragmentaryzacja\%20w\%20mediach.pdf, 12.12.2010. Smith Mark. 1992. Voices from the Well: the Logic of the Virtual Commons. http:// www.sscnet.ucla.edu/soc/csoc/papers/voices/Voices.htm, 2.01.2011. 